\title{
HUBUNGAN KEBERSIHAN PERSONAL DENGAN INFEKSI CACING Soil Transmitted Helminth (STH) PADA FESES ANAK SDN 1 KEDAMEAN KABUPATEN GRESIK
}

\author{
Elis Anita Farida ${ }^{1}$, Siti Zainab Salim ${ }^{2}$, Meilina Dewi Masyithoh ${ }^{3}$, Acivrida \\ Mega Charisma ${ }^{4}$, Khurin In Wahyuni ${ }^{5}$
}

STIKES RS Anwar Medika

Email: elza.syarief@yahoo.com

\begin{abstract}
ABSTRAK: Infeksi cacing merupakan penyakit endemik kronik yang di akibatkan satu atau lebih cacing yang masuk kedalam tubuh manusia, dengan prevalensi tinggi terdapat pada anak-anak. Infeksi cacing yang menjadi masalah utama adalah kelompok Soil Transmitted Helminths (STH) diantaranya Ascaris lumbricoides, Trichuris trichiura, Necator americanus dan Ancylostoma duodenale. Penelitian ini bertujuan untuk mengetahui apakah siswa SDN 1 Kedamean terinfeksi telur cacing Soil Transmitted Helminth (STH) dan untuk mengetahui adanya hubungan personal kebersihan dengan prevalensi kecacingan pada feses anak SDN 1 Kedamean. Penelitian ini menggunakan teknik Random Sampling yaitu semua siswa kelas 3 SD sampai kelas 5 SD yang memenuhi kriteria inklusi dan eksklusi. Banyaknya sampel penelitian ini adalah 30 sampel yang diambil dari kelas 3, 4, dan 5 dan dianalisis menggunakan Statistika fisher exact. Pada penelitian ini diperoleh 5 siswa yang terinfeksi telur cacing Soil Transmitted Helminth (STH) yang ditemukan yaitu telur cacing Ascaris lumbricoides, Trichuris trichiura, dan Hookworm. Yang terinfeksi Soil Transmitted Helminth (STH) lebih banyak menginfeksi laki-laki (10\%) sedangkan pada anak perempuan (6,7\%). Dari hasil penelitian disimpulkan bahwa tidak terdapat hubungan antara infeksi cacing dengan kebersihan personal siswa SDN 1 Kedamean.
\end{abstract}

Kata kunci: Higiene perorangan, Infeksi cacing usus, Siswa Sekolah Dasar, Perilaku siswa 
Artikel Penelitian

\begin{abstract}
Worm infection is a chronic endemic disease caused by one or more worms that enter the human body, with a high prevalence found in children. Worm infections that become the main problem are the Soil Transmitted Helminths (STH) groups including Ascaris lumbricoides, Trichuris trichiura, Necator americanus and Ancylostoma duodenale. This study aims to determine whether students of Kedamean Elementary School 1 are infected with Soil Transmitted Helminth (STH) worm eggs and to determine the relationship of personal hygiene with the prevalence of intestinal worms in the feces of children of SDN 1 Kedamean. This study uses a Random Sampling technique that is all grade 3 students from grade 5 to grade 5 who meet the inclusion and exclusion criteria. The number of samples in this study were 30 samples taken from classes 3,4 , and 5 and analyzed using Fisher exact statistics. In this study, 5 students who were infected with Soil Transmitted Helminth (STH) worm eggs were found, namely Ascaris lumbricoides, Trichuris trichiura, and Hookworm eggs. Those infected with Soil Transmitted Helminth (STH) infect more men $(10 \%)$ while in girls $(6.7 \%)$. From the results of the study concluded that there was no relationship between helminth infections and personal higiene of SDN 1 Kedamean students.
\end{abstract}

Keywords: Individual hygiene, Soil Transmitted Helminth, Elementari School Students, Students Behavior

\title{
PENDAHULUAN
}

Indonesia adalah salah satu negara beriklim tropis yang memiliki kelembapan tinggi dan lingkungan yang baik untuk berkembang biaknya cacing, terutama Soil Transmitted Helminths (STH). Lebih dari 1,5 milyar atau 24\% dari seluruh populasi didunia terinfeksi cacing terutama di daerah tropis dan subtropis dengan jumlah terbesar terjadi sub Sahara, Amerika, Afrika, China, dan Asia Timur (WHO, 2012). Angka prevalensi menurut data Depkes RI kecacingan di Indonesia pada tahun 2015 adalah 28,12\% lebih dari 270 juta anak-anak usia perkelas dan lebih dari 600 juta anak usia sekola tinggal didaerah dimana parasit ini secara intensif di tularkan dan membutuhkan pengobatan dan intervensi pencegahan (Farisa, 2012). Di Indonesia penyakit infeksi cacing mempunyai prevalensi yang cukup tinggi yaitu sekitar $60 \%$ dari 220 juta penduduk dan $21 \%$ diantaranya menyerang anak usia sekolah dasar. Kecacingan merupakan penyakit endemik kronik yang di akibatkan satu atau lebih cacing yang masuk kedalam tubuh manusia, dengan prevalensi tinggi terdapat pada anak-anak (Farisa, 2012).

Infeksi cacing yang menjadi masalah utama adalah kelompok Soil Transmitted Helminths (STH) diantaranya Ascaris lumbricoides, Trichuris trichiura, Necator americanus dan Ancylostoma duodenale (Djarismawati, 2008).

Infeksi STH dapat menyebabakan kekurangan gizi, anemia dan juga dapat mempengaruhi pertumbuhan fisik, mental pada masa kanak-kanak (Hotez et al., 2004). Infeksi Soil Transmitted Helmiths (STH) masih merupakan endemik di 


\section{Artikel Penelitian}

banyak daerah di Dunia, terutama di negara yang sedang berkembang contohnya seperti Indonesia, China, Mesir, dan India dengan sanitasi lingkungan dan kebersihan diri yang sangat kurang. Diperkirakan sekitar 807 juta manusia di Dunia terinfeksi Ascaris lumbricoides, sekitar 604 juta menderita trikuriasis dan Hookworm menginfeksi sekitar 576 juta manusia di seluruh dunia. Infeksi cacing dapat terjadi secara simultan oleh beberapa jenis cacing sekaligus pada anak-anak cacing akan berdampak pada gangguan kemampuan untuk belajar, pada orang dewasa akan menurunkan produktifitas kerja dalam jangka panjang. Infeksi cacing ini dapat dipengaruhi oleh beberapa faktor yaitu faktor lingkungan, faktor kebersihan, sosial ekonomi, dan tingkat pengetahuan orang tua terhadap hubungan kebersihan dan penyakit infeksi cacing (Arfina, 2011).

Penelitian Rahmawati (2009) menunjukkan. Infeksi kecacingan dapat dipengaruhi oleh kebersihan perorangan seperti kebersihan tangan dan kuku. Infeksi cacingan kebanyakan ditularkan melalui tangan yang kotor, kuku jemari tangan yang kotor dan panjang sering tersimpan telur cacing. Kebanyakan penyakit cacing ditularkan melalui tangan dan kaki yang kotor serta kuku yang panjang terselip oleh telur cacing. Keberadaan STH dari 139 responden ditemukan 76,3\% (106 responden) positif terdapat telur cacing dan seluruhnya $100 \%$ merupakan jenis telur cacing Ancylostoma duodenale. Jumlah telur cacing Ancylostoma duodenale berkisar antara 1-25, dengan kategori 6-10 (36\%) 50 responden yang merupakan kelompok jumlah telur tertinggi dengan infeksi ringan (Rahmawati, 2009) .

Lokasi penelitian dilakukan di sekolah SDN 1 di Desa Kedamean Kabupaten Gresik karena diduga kebiasaan siswa setiap yang memakai alas kaki, tidak mencuci tangan sebelum makan, tidak mencuci tangan dengan sabun setelah buang air besar (BAB), bermain tanah, dan kuku tangan yang tidak bersih dan panjang sehingga dengan kondisi tersebut dapat menjadi faktor penyebab resiko terjadinya infeksi cacing pada anak dimungkinkan dapat terjadi. Berdasarkan latar belak mang diatas maka maksud dari penelitian ini adalah untuk melihat hubungan personal kebersihan dengan infeksi cacing Soil Transmitted Helminth pada feses anak SDN 1 Kedamean Kabupaten Gresik.

\section{METODE}

\section{Waktu dan Tempat Penelitian}

Penelitian ini akan dilaksanakan pada bulan Juni-Juli di Sekolah SDN 1 Kedamean kabupaten Gresik. Tempat dilakukannya pengujian adalah di Laboratorium Biologi Terpadu STIKES Rumah Sakit Anwar Medika. 


\section{Artikel Penelitian}

\section{Rancangan Penelitian}

Penelitian ini dilakukan dengan Deskriptif Kuantitatif untuk mengidentifikasi adanya telur cacing nematoda usus pada feses anak SDN 1 Kedamean. Adapun variabel yang terdapat dalam penelitian ini adalah: Variabel Bebas

Variabel bebas dalam penelitian ini adalah keberadaan telur cacing Soil Transmitted Helminth (STH) pada feses anak SDN 1 Kedamean. Variabel Terikat

Variabel terikat dalam penelitian ini adalah sampel fese anak SDN 1 Kedamean.

\section{Tahapan Penelitian}

Penelitian ini menggunakan Random Sampling yang dilakukan dengan memberikan intervensi atau perlakuan untuk kemudian dilihat hasil pengamatan. Dengan tahapan penelitian yang akan dilakukan adalah pengambilan sampel dari sekolah SDN 1 Kedamean lalu dilakukan uji makroskopis lalu di lakukan pewarnaan Eosin 2\%.

\section{Langkah Penelitian \\ Populasi dan sampel}

Penelitian ini dengan menggunakan teknik random sampling yaitu suatu cara pengambilan sampel dengan memberikan kesempatan atau peluang yang sama untuk diambil pada setiap populasi. Sampel penelitian untuk pemeriksaan tinja adalah anak sekolah dasar dengan kriteria inklusi.

Populasi penelitian merupakan populasi terbatas (anak SDN 1 Kedamean) sehingga ditentukan rumus besar sampel menurut Slovin yaitu sebagai berikut:

Kriteria inklusi sebagai berikut:

a. Berjenis kelamin laki-laki dan perempuan

b. Berumur antara 8-12 tahun

c. Anak yang bersedia mengumpulkan tinja

d. Anak yang mendapat izin dari orang tua 
Artikel Penelitian

\section{Prosedur Kerja}

\section{Pengambilan Spesimen}

Diambil kira-kira 100 gram tinja dalam wadah yang bersih dan kering tanpa pengawet. Wadah yang paling cocok adalah wadah yang bertutup rapat (pot sampel). Hal-hal yang harus diperhatikan yaitu tinja jangan sampai terpapar udara dalam wadah tanpa penutup dan tidak boleh tercampur urine. Tinja harus di periksa dalam 1-4 jam setelah pengambilan.

\section{Perwarna Eosin 2\%}

Pertama kaca objek dibersihkan dengan menggunakan etanol 95\% kemudian dioleskan sedikit sampel feses dan diteteskan larutan eosin 2\% diatas kaca objek, diratakan diatas kaca objek dengan ukuran kira-kira $2 \times 1 \mathrm{~cm}$, ditutup preparat dengan penutup kaca objek. Diamati dengan mikroskop hingga perbesaran 400x dengan titik pengambilan yang diamati sebanyak satu kali.

\section{Analisa Data}

Data yang diperoleh dianalisa secara deskriptis kuantitatif dengan melihat ada atau tidaknya Soil Transmitted Helmint pada siswa SD. Hasil yang diperoleh dibuat dalam bentuk desain cross sectional dan SPSS kemudian data tersebut di sajikan dalam bentuk tabel. Hasilnya digunakan untuk menarik kesimpulan.

\section{HASIL DAN PEMBAHASAN}

\section{Karakteristik Responden Siswa SDN 1 Kedamean}

Penelitian ini dilakukan di SDN 1 Kedamean yang kemudian dilakukan pemeriksaan feses di laboratorium Biologi Terpadu STIKES RS Anwar Medika menggunakan Mikroskop Binokuler perbesaran $10 \times 40$ berupa data pengamatan. data tersebut dianalisis secara statistika fisher exact. Adapun hasil pengamatan berikut ini disajikan pada tabel 4.1

Berdasarkan Tabel dan Grafik 4.1 dari 30 responden yang terdiri dari kelas 3 , 4, dan 5 didapatkan siswa yang positif ditemukan telur cacing hanya 5 siswa $(16,7 \%)$ dan yang negatif tidak ditemukan telur cacing sebanyak 25 siswa $(83,3 \%)$. Adapun karakteristik responden pada siswa SDN 1 Kedamean dapat disajikan pada tabel 4.2.

Berdasarkan Tabel dan Grafik 4.2, jumlah responden sebanyak 30 siswa dan jumlah responden siswa yang berjenis kelamin perempuan sebanyak 17 siswa $(56,6 \%)$ dan yang berjenis kelamin laki-laki sebanyak 13 siswa $(43,3 \%)$ dari kedua karakteristik tersebut yang lebih banyak adalah yang berjenis kelamin perempuan, sedangkan jumlah responden berdasarkan usia diantaranya, usia 8 tahun sebanyak 4 siswa (13,3\%), usia 9 tahun sebanyak 10 siswa $(33,3 \%)$, usia 10 tahun sebanyak 6 siswa (20\%), usia 11 tahun sebanyak 8 siswa $(26,6 \%)$, dan 
Artikel Penelitian

usia 12 tahun hanya 2 siswa (6,6\%). Jadi, usia terbanyak sebagai responden adalah usia 9 tahun sebanyak 10 siswa (33,3\%). Jumlah tingkatan terbanyak dari kelas IV sebanyak 11 siswa $(36,6 \%)$, diikuti dengan kelas III sebanyak 10 siswa (33,3\%), dan jumlah yang sedikit dari kelas V hanya 9 siswa (30\%). Didapatkan pengelompokkan berdasarkan jenis cacing yang terdiri dari cacing Ascaris lumbricoides hanya ditemukan 2 siswa (6,6\%) yang terinfeksi, cacing Trichuris trichiura hanya ditemukkan 2 siswa $(6,6 \%)$, dan cacing Hookworm hanya ditemukkan 1 siswa (3,3\%) yang terinfeksi. Hasil dari Tabel dan Grafik 4.2 menunjukkan pada kelompok kasus terdapat 26 siswa $(86,7 \%)$ yang melakukan kebiasaan mencuci tangan dengan baik dan hanya 5 siswa (16,7 \%) siswa yang tidak melakukan kebiasaan mencuci tangan yang buruk, pada siswa yang melakukan kebiasaan minum obat dengan persentasi 19 siswa $(63,3 \%)$ dan lebih tinggi dari persentasi siswa yang tidak minum obat cacing sebanyak $(63,3 \%)$, sedangkan persentasi siswa yang memakai alas kaki lebih tinggi pada kategori sering yaitu sebanyak 27 siswa (90\%) sedangkan yang jarang menggunakan alas kaki hanya 3 siswa (10\%). Dan presentasi kebiasaan memotong kuku lebih sering sebanyak 22 siswa $(73,3 \%)$ sedangkan yang tidak sering memotong kuku hanya 8 siswa $(26,7 \%)$.

\section{Hubungan Kebiasaan Personal Kebersihan dengan Infeksi Soil Transmitted Helmint (STH)}

Penelitian ini menggunakan 4 indikator sebagai kelompok kebiasaan personal kebersihan diantaranya kebiasaan mencuci tangan, minum obat cacing, memakai alas kaki, dan memotong kuku. Indikator tersebut dianalisis secara statistika menggunakan desain penelitian cross sectional untuk mengetahui adanya hubungan dengan infeksi Soil Transmitted Helminth (STH) dengan nilai signifikansi $<0,05$. Berikut ini hasil data secara statistika masing-masing indikator:

\section{Hubungan Kebiasaan Minum Obat Cacing Dengan Infeksi Soil Transmitted Helminth (STH)}

Indikator kebiasaan minum obat cacing ini bertujuan untuk mengetahui seberapa banyak siswa yang minum obat cacing yang kemudian dihubungkan dengan jumlah siswa yang terinfeksi Soil Transmitted Helminth (STH) secara statistika. Menurut Tabel 4.3, dari 11 siswa yang tidak minum obat cacing terdapat 9 siswa $(81,8 \%)$ yang tidak terinfeksi Soil Transmitted Helminth (STH) dan yang terinfeksi Soil Transmitted Helminth (STH) hanya 2 siswa $(18,2 \%)$, sedangkan dari 19 siswa yang minum obat cacing terdapat 16 siswa $(84,2 \%)$ yang tidak terinfeksi Soil Transmitted Helminth (STH) dan yang terinfeksi hanya 3 siswa (15,8 \%). Berdasarkan uji fisher exact didapatkan nilai signifikansi 0,619 (data terlampir) yang berarti $>0,05$ sehingga kebiasaan minum obat cacing tidak 
Artikel Penelitian

terdapat hubungan yang bermakna terhadap infeksi Soil Transmitted Helminth (STH).

\section{Hubungan Kebiasaan Mencuci Tangan dengan Infeksi Soil Transmitted Helminth (STH)}

Indikator kebiasaan mencuci tangan ini bertujuan untuk mengetahui seberapa banyak siswa SDN 1 Kedamean yang membiasakan diri mencuci tangan sebelum maupun setelah bermain tanah, kemudian dihubungkan dengan jumlah siswa yang terinfeksi cacing Soil Transmitted Helminth (STH) secara statistika. Menurut Tabel 4.4, dari 4 siswa yang tidak melakukan kebiasaan mencuci tangan terdapat 3 siswa $(75,0 \%)$ yang tidak terinfeksi cacing Soil Transmitted Helminth (STH), dan yang terinfeksi cacing Soil Transmitted Helminth (STH) hanya 1 siswa (25,0 \%). Sedangkan dari 24 siswa yang membiasakan diri mencuci tangan sebelum dan setelah bermain tanah yang tidak terinfeksi cacing STH sebanyak 22 siswa $(15,4 \%)$, dan yang terinfeksi cacing Soil Transmitted Helminth (STH) hanya 4 siswa (15,4 \%).

Berdasarkan uji fihser exact diperoleh nilai signifikansi 0,538 (data terlampir) yang berarti $>0,05$ sehingga kebiasaan mencuci tangan tidak ada hubungan bermakna dengan infeksi cacing Soil Transmitted Helminth (STH).

\section{Hubungan Kebiasaan Memakai Alas Kaki Dengan Infeksi Soil Transmitted Helminth (STH)}

Indikator kebiasaan memakai alas kaki ini bertujuan untuk mengetahui seberapa banyak siswa SDN 1 Kedamean yang sering menggunakan alas kaki pada saat di lingkungan sekolah maupun dilingkungan keluarga. Kemudian dihubungkan dengan jumlah siswa yang terinfeksi cacing Soil Transmitted Helminth (STH) secara statistika. Menurut Tabel 4.5, dari 3 siswa yang tidak melakukan kebisaan mencuci tangan terdapat 2 siswa $(66,7 \%)$ yang tidak terinfeksi Soil Transmitted Helminth (STH), dan 1 siswa $(33,3 \%)$ yang terinfeksi Soil Transmitted Helminth (STH). Sedangkan dari 27 siswa yang melakukan kebiasaan memakai alas kaki terdapat 23 siswa $(85,2 \%)$ yang tidak terinfeksi Soil Transmitted Helminth (STH), dan yang terinfeksi STH hanyan 4 siswa $(14,8 \%)$. Berdasarkan uji fihser exact diperoleh nilai signifikansi 0,433 (data terlampir) yang berarti $>0,05$ sehingga kebiasaan memakai alas kaki tidak ada hubungan bermakna dengan infeksi cacing.

\section{Hubungan Kebiasaan Memotong Kuku Dengan Infeksi Soil Transmitted Helminth (STH)}

Indikator kebiasaan memotong kuku ini bertujuan untuk mengetahui seberapa banyak siswa SDN 1 Kedamean yang sering memotong kuku. Kemudian dihubungkan dengan jumalah siswa yang terinfeksi cacing Soil Transmitted 
Artikel Penelitian

Helminth (STH) secara statistika. Menurut Tabel 4.6 dari 7 siswa yang tidak melakukan kebiasaan memotong kuku sebanyak 6 siswa $(85,7 \%)$ yang tidak terinfeksi cacing Soil Transmitted Helminth (STH) dan 1 siswa (14,3\%) yang terinfeksi cacing. Sedangkan dari 23 siswa yang melakukan kebiasaan memotong kuku terdapat 19 siswa $(82,6 \%)$ yang tidak terinfeksi dan yang terinfeksi hanya 4 siswa (17,4\%). Berdasarkan uji fihser exact diperoleh nilai signifikansi 0,671 (data terlampir) yang berarti $>0,05$ sehingga kebiasaan memotong kuku tidak ada hubungan bermakna dengan infeksi Soil Transmitted Helminth (STH).

\section{Pembahasan}

Berdasarkan hasil pengolahan data yang dianalisis menggunakan satistika fisher exact dengan desain cross sectional didapatkan hasil penelitian pada siswa SDN 1 Kedamean menunjukkan bahwa dari 30 subjek yang dilakukan pemeriksaan feses secara laboratorium, terdapat 5 (16,7\%) subjek yang positif terinfeksi Soil Transmitted Helminth (STH). Infeksi tunggal Ascaris lumbricodes 2 (6,6\%) subjek, infeksi tunggal Trichuris trichiura 2 (6,6\%)subjek, dan infeksi tunggal Hookworm $1(3,3)$ subjek, dan tidak ditemukkannya infeksi cacing tambang. Adapun beberapa indikator yang mendasari penelitian ini dapat diuraikan sebagai berikut:

\section{Hubungan Antara Mengkonsumsi Obat Cacing Dengan Infeksi Cacing Soil Transmitted Helminth (STH) Pada Anak SDN 1 Kedamean Kabupaten Gresik}

Berdasarkan penelitian yang telah dilakukan di SDN 1 Kedamean Kabupaten Gresik didapatkan hasil tidak ada hubungan antara kebiasaan minum obat cacing dengan kejadian kecacingan, hal ini karena sebagian besar anakanak sudah melakukan kebiasaan minum obat cacing setiap 6 bulan sekali. penelitian ini mendukung penelitian sebelumnya yang dilakukan oleh (Anwar, Dkk., 2013) bahwa tidak ada hubungan antara minum obat cacing dengan infeksi Soil Transmitted Helminth (STH) karena sebagian besar siswa sudah membiasakan diri minum obat cacing setiap 6 bulan sekali.

Pengobatan dengan cara minum obat cacing 6 bulan sekali didasarkan pada siklus hidup cacing dari mulai masuknya telur hingga menjadi larva dan menginfeksi manusia. Pencegahan kecacingan disarankan oleh WHO difokuskan pada penduduk beresiko tinggi. Pemberian obat cacing pada anak-anak diberikan apabila lebih dari 10\% kejadian kecacingan (Chin,2012). Pemberian obat cacing pada setiap penderita dapat menyembuhkan penderita dengan tingkat kesembuhan 70-99\% (Depkes RI, 2004).

Berdasarkan data statistika bahwa uji chi square test harus mempunyai nilai yang lebih dari 5, sehingga peneliti menggunakan fisher exact dalam penelitian 


\section{Artikel Penelitian}

ini. Karena tujuan dari peneliti adalah untuk melihat hubungan antara kebiasaan minum obat cacing siswa SDN 1 Kedamean dengan infeksi cacing maka dilihat ecact sig.2-sided (data terlampir) yang nilai signifikansi $=1,00$ sehingga peneliti menyimpulkan bahwa tidak terdapat hubungan antara kebiasaan minum obat cacing dengan infeksi Soil Transmitted Helminth (STH).

\section{Hubungan Kebiasaan Mencuci Tangan Dengan Infeksi Cacing Soil Transmitted Helminth (STH) Pada Anak SDN 1 Kedamean Kabupaten Gresik}

Berdasarkan data statistika yang diperoleh pada uji chi square test fisher exact bahwa mempunyai nilai kurang dari 5. Karena tujuan dari penelitian ini adalah untuk melihat apakah ada hubungan antara kebiasaan mencuci tangan dengan infeksi Soil Transmitted Helminth (STH) pada siswa SDN 1 Kedamean maka dilihat exact sig.2-sided (data terlampir) yang nilai signifikansi $=0,05$ $(>0,05)$ sehingga peneliti menyimpulkan bahwa ada hubungan antara kebiasaan mencuci tangan dengan infeksi Soil Transmitted Helminth (STH).

Hasil penelitian menunjukkan 30 responden pada kelompok kasus terdapat 26 siswa $(86,7 \%)$ yang mencuci tangan dan 5 siswa $(16,7 \%)$ yang tidak melakukan kebiasaan mencuci tangan, sehingga pada penelitian ini ada hubungan antara kebiasaan mencuci tangan dengan infeksi cacing STH. Penelitian ini sesuai dengan penemuan dari Irawati (2013) bahwa ada hubungan antara kebiasaan mencuci tangan dengan infeksi Soil Transmitted Helminth (STH) pada anak di wilayah kerja puskesmas Tamangapa Antang Makassar, hasil penemuan Budi (2012) juga menemukan adanya hubungan antara kebiasaan mencuci tangan dengan infeksi Soil Transmitted Helminth (STH) pada siswa SD Manado.

Dari penelitian ini juga terdapat 4 anak 13,3\% yang mencuci tangan sebelum dan sesudah makan tetapi mengalami cacingan, peneliti berasumsi bahwa masih terinfeksinya anak walaupun sudah mencuci tangan karena mereka mencuci tangan hanya dengan air saja tanpa memakai sabun, sehingga kumankuman masih ada yang menempel ditangan. Hal tersebut sesuai dengan teori Suzannita (2013) yang mengatakan mencuci tangan dengan menggunakan air saja merupakan hal yang umum dilakukan, namun kebiasaan ini kurang efektif dibandingkan dengan cuci tangan memakai sabun, pasalnya sabun dapat menghilangkan lemak dan kotoran yang mengandung kuman.

\section{Hubungan Antara Kebiasaan Memakai Alas Kaki Dengan Infeksi Cacing Soil Transmitted Helminth (STH) Pada Siswa SDN 1 Kedamean Kabupaten Gresik}

Berdasarkan hasil statistika yang diperoleh pada uji chi square test bahwa mempunyai nilai yang kurang dari 5, sehingga peneliti menggunakan fisher excat 


\section{Artikel Penelitian}

dalam penelitian ini. Karena tujuan dari peneliti adalah untuk melihat apakah ada hubungan antara kebiasaan memakai alas kaki siswa SDN 1 Kedamean dengan infeksi STH maka dilihat nilai excat sig.2-sided (data terlampir) yang nilai signifikansi $=0,04$, sehingga peneliti menyimpulkan bahwa tidak terdapat hubungan antar kebiasaan memakai alas kaki dengan infeksi Soil Transmitted Helminth (STH).

Hasil penelitian menunjukkan pada kelompok kasus yang memiliki kebiasaan memakai alas kaki sebanyak 27 anak (90\%) sedangkan pada kelompok kontrol yang tidak memakai alas kaki sebanyak 3 anak (10\%).Penelitian ini sejalan dengan yang dilakukan oleh (Rahmad, 2008) di Kec. Sibolga Kota, Endriani et al. tahun 2010 di Kel. Karangroto Semarang dan Nusa et al tahun 2013 di Kab. Kep. Talaud bahwa tidak ada hubungan yang bermakna antara penggunaan alas kaki dengan infeksi cacing usus dan didukung juga oleh penelitian Ghassani (2011) pada SDN 09 Pagi Paseban tahun 2010 bahwa tidak ada hubungan bermakna antara kebiasaan memakai alas kaki dengan infeksi cacing Soil Transmitted Helminth (STH) hal ini kemungkinan karena anak-anak sudah membiasakan diri memakai alas kaki pada saat bermain tanah baik dilingkungan sekolah maupun dilingkungan keluarga, sehingga dapat mencegah terjadinya infeksi cacing. Seperti yang dijelaskan pada teori Gandahusada (2006) bahwa kulit merupakan tempat masuknya bibit penyakit ke dalam tubuh. Tanah gembur (pasir, humus) merupakan tanah yang baik untuk pertumbuhan larva cacing. Jika seseorang menginjakkan kakinya ditanah tanpa menggunakan alas kaki dan jika kebersihan serta pemeliharaan kaki tidak diperhatikan maka dapat menjadi sasaran masuknya kuman-kuman penyakit ke dalam tubuh, termasuk larva cacing. Depkes RI (2001) juga menjelaskan telur dan larva cacing banyak terdapat di tanah. Semakin sering kontak dengan tanah maka resiko terinfeksi cacing semakin besar.

Pemakaian alas kaki dapat mencegah terjadinya infeksi luka serta infeksi kecacingan. Anak usia sekolah merupakan kelompok rentan terinfeksi cacing karena pola bermain anak pada umumnya tidak dapat dilepaskan dari tanah sementara itu pada saat anak bermain seringkali lupa menggunakan alas kaki.

\section{Hubungan Antara Kebiasaan Memotong Kuku Dengan Infeksi Cacing Soil Transmitted Helminth (STH) Pada Siswa SDN 1 Kedamean Kabupaten Gresik}

Berdasarkan data statistika yang diperoleh pada uji chi square test bahwa mempunyai nilai kurang dari 5, sehingga peneliti menggunakan fisher exact dalam penelitian ini. Karena tujuan dari penelitian ini adalah untuk melihat apakah ada hubungan antara kebiasaan memotong kuku dengan infeksi STH pada siswa SDN 1 Kedamean maka dilihat exact sig. 2-sided (data terlampir) yang nilai 


\section{Artikel Penelitian}

signifikansi $=1,00(>0,05)$ sehingga peneliti menyimpulkan bahwa tidak ada hubungan antara kebiasaan memotong kuku dengan infeksi Soil Transmitted Helminth (STH).

Hasil penelitian menunjukkan pada kelompok kasus yang memiliki kebiasaan memakai alas kaki sebanyak 22 anak (73,3\%) sedangkan pada kelompok kontrol yang tidak memakai alas kaki sebanyak 8 anak $(26,7 \%)$. Penelitian yang sama oleh Nadesul (2000) mengemukakan bahwa telur cacing sering kali terselip pada kuku yang kotor. Kondisi ini sering terjadi pada anak yang sering bermain ditanah serta pada orang dewasa yang bekerja dikebun atau disawah. Onggowaluyo (2001) juga menjelaskan bahwa penularan infeksi cacingan bisa saja melalui kuku jari tangan yang panjang yang kemungkinan terselip telur cacing dan nantinya bisa tertelan ketika makan.

\section{Kesimpulan}

Berdasarkan hasil penelitian tentang Hubungsn Persolan Kebersihan Dengan Infeksi Cacing Soil Transmitted Helminth (STH) Pada Feses Anak SDN 1 Kedamean Kabupaten Gresik dapat disimpulkan sebagai berikut:

a. Pemeriksaan feses di SDN 1 Kedamean ditemukan adanya infeksi cacing Soil Transmitted Helminth (STH) sebanyak 5 siswa.

b. Tidak terdapat hubungan yang bermakna antara kebiasaan minum obat cacing, kebiasaan mencuci tangan, kebiasaan memakai alas kaki, dan kebiasaan memotong kuku dengan infeksi Soil Transmitted Helminth (STH) pada feses anak SDN 1 Kedamean.

\section{Saran}

Perlu dilakukan pemeriksaan dan pengobatan secara berkala tiap 6 bulan sekali pada siswa SDN 1 Kedamean. Peningkatan perilaku hidup bersih dan sehat (PHBS) perlu dilakukan program penyuluhan dalam memberantas infeksi cacing usus Soil Transmitted Helminth yang diperuntukkan terutama melalui orang tua. Program penyuluhan kesehatan disamping meningkatkan pengetahuan orang tua, diharapkan pula akan meningkatkan kesadaran mereka untuk melakukan upaya pencegahan dan pengobatan secara mandiri. 
Artikel Penelitian

\section{DAFTAR PUSTAKA}

1. Andaruni A. 2012. Gambaran faktor-faktor penyebab infeksi cacingan pada anak di SDN 01 pasirlangu cisarua. Students e-Journal. 1(1): 1-15.

2. Arfina, D. 2011. Hubungan Menyiram Menggunakan Air Sumur Dengan Kontaminasi Soil Transmitted Helminth Pada Tanaman Kubis di Desa Seribu Dolok Simalungan Sumatera Utara. Skripsi Sarjana, Fakultas Kedokteran Universitas Sumatera Utara, Medan.

3. ATIKA Ghassani, 2013. Hubungan Infeksi Cacing Usus STH Dengan Kebiasaan Bermain Tanah Pada SDN 09 Pagi Paseban Tahun 2010

4. Budi, 2012. Hubungan Antara Higiene Perorangan Dengan Infestasi Cacing Usus Pada Siswa Sekolah Dasar Negeri 119 Manado.

5. Departemen Kesehatan R.I. 2001. Pedoman Modul dan Materi Pelatihan "Dokter Kecil". Jakarta: Depkes R.I.

6. Djarismawati, 2008. Prevalensi Cacing Usus Pada Murid Sekolah Dasar Wajib Belajar Pelayanan Gerakan Terpadu Pengentasan Kemiskinan Daerah Kumuh di Wilayah DKI Jakarta, Jurnal Ekologi Kesehatan, 7 (2): 769-774.

7. Etjang, Indian. 2003 Mikrobiologi dan Parasitologi. Bandung: PT. Citra Aditya Bakti.

8. Fatimah farisa, 2012. Derajat Keparahan Infeksi STH Terhadap Status Gizi Dan Anemia Pada Anak Sekolah Dasar.

9. Fitri, J., Saam, Z., Hamidy, MY. 2012. “Analisis Faktor-Faktor Risiko Infeksi Kecacingan Murid Sekolah Dasar Di Kecamatan Angkola Timur Kabupaten Tapanuli Selatan Tahun 2012"

10. Fusvita, Anggriani. 2017. Identifikasi Telur Nematoda Usus (Soil Transmitted Helmiths) Pada Anak Di Tempat Pembuangan Akhir (TPA) Puuwatu Jakarta: EGC; 2009

11. Gandahusada, S, 2006, Parasitologi Kedokteran, Edisi ketiga, Jakarta:balai penerbit: FKUI.

12. Gandahusada, Sriasi, dkk. 2006. Parasitologi Kedokteran. Cet. VI; Jakarta: FKUI.

13. Gandahusada, Sriasi, dkk. 2006. Parasitologi Kedokteran. Cet. VI; Jakarta: FKUI

14. Haerani B, Waris L, Juhairiyah.2014. revalence of Soil Transmitted Helminths (STH) in primary school children in subdistrict of Malinau Kota, District of Malinau, Sudarto, 2007. Penuntun Parasitologi Kedokteran, PT Gramedia, Jakarta (Hal.2)

15. Hariyani. 2010. Hubungan Hygiene Sanitasi Perorangan Dengan Kejadian Penyakit Cacingan Pada Siswa Sekolah Dasar Yayasan Dinamika Indonesia Bantar Gerbang Bekasi Jawa Barat. 


\section{Artikel Penelitian}

16. Haryati, Siti. 2004. Hubungan Praktek Kebersihan Diri Dan Higiene Perseorangan Dengan Kejadian Kecacingan Perut Pada Pemulung Di Tpa Gunung Tugel Kabupaten Banyumas

17. Hotez PJ, Brooker S, Bethony JM, Bottazzi ME, Loukas A, Xiao S. 2004. Current concepts: Hookworm infection. New England Journal of Medicine.;351:799-807

18. Irawati, 2013. Hubungan Personal Hygiene Cacingan Pada Anak Di Wilayah Kerja Puskesmas Tamangapa Antang Makassar

19. Irianto Koes, 2013. Parasitologi Medis.Alfa Beta Bandung

20. Jaya I.K.S. dan Romadilah. 2013. Hubungan infeksi kecacingan dan personal higiene dengan kadar hemoglobin (hb) Siswa sdn 51 cakranegara kota Mataram tahun 2013. Media Bina Ilmiah. 7(1): 42-45.

21. Juni Prianto LA, Tjahaya P.U. Darwanto, Atlas Parasitologi Kedokteran Editor. Prof. Dr.dr.Pinardi Hadidjaja. MPH \& TM dr. Seisasi Gandahusada GM 20394.146.1994. $288 \mathrm{hlm}: 24 \mathrm{~cm}$. Jakarta

22. Jusuf A, Ruslan, dan Selomo M. 2013. Gambaran parasit soil transmited helminth dan tingkat pengetahuan, sikap, serta tindakan petani sayur di desa Waiheru, kecamatan baguala kota ambon

23. Mandal, B., dkk. 2008. Penyakit Infeksi. Ed. VI; Jakarta: Erlangga.

24. Muslim H. M. 2009 Buku Ajar Helmintologi Medik, Akademi Analis Kesehatan Borneo Lestari : Banjarbaru

25. Muslim,H.M. 2015. Buku Ajar Helmintologi, Akademi Analis Kesehatan Borneo Lestari : Banjar baru East Kalimantan Province. Jurnal Buski , 5 (1): 43-48

26. Nadesul, Hendrawan. 2000. “Bagaimana Kalau Cacingan?”. Cet. 3; Jakarta: Puspa

27. Natadisastra, D. Agoes R. Parasitologi kedokteran: ditinjau dari tubuh yang diserang. Jakarta: EGC; 2009

28. Onggowaluyo, J. S. 2001. Parasitologi Medik 1 Helmintologi. Jakarta: EGC

29. Palgunadi BU. 2010. Faktor-faktor yang mempengaruhi kejadian kecacingan yang disebabkan oleh soil-transmited-helminth di Indonesia. Jurnal Ilmiah Kedokteran Khusus. 1 (1): 1-5.

30. Prasetyo R. Heru. 2013. Buku Ajar Parasitologi Kedokteran, Parasit Usus. CV Sagung Seto.

31. Rahmawati S, L, 2009, Hubungan Antara Sanitasi Lingkungan Rumah dan Praktek Kebersihan Diri Dengan Kejadian Kecacingan (studi kasus pada murid SD negeri Asinan 01 Desa Asinan kecamatan Bawen kabupaten Semarang), Universitas Diponegoro, Semarang

32. Rizka Yunidha Anwar, Dkk., 2013. Hubungan Antara Higiene Perorangan Dengan Infeksi Cacing Usus (Soil Transmitted Helminth) 2013 